\title{
PENGARUH MODEL PROBLEM BASED LEARNING TERHADAP KEMAMPUAN PEMECAHAN MASALAH MATEMATIS SISWA KELAS VII SMPN SE-KABUPATEN KUANTAN SINGINGI PADA MATERI ARITMETIKA SOSIAL
}

\author{
Erpina Ulva ${ }^{1}$, Maimunah $^{2}$, Atma Murni $^{3}$ \\ ${ }^{1,2,3}$ FKIP, Universitas Riau \\ erpina.u@gmail.com
}

\begin{abstract}
The purpose of this study was to determine the effect of the application of the Problem Based Learning (PBL) model on students' mathematical problem solving abilities (MPSA) in Social Arithmetic material. This research was conducted to see the effect of the application of the PBL model on student MPSA in terms of all high, medium and low level students and in terms of each level of the school that was the research sample. This study used an experimental method with a pre-test post-test control group design. The population in this study were students of class VII SMP Negeri in Kuantan Regency. The population comes from high, medium, and low level schools. The samples in this study were SMP Negeri 1 Taluk Kuantan (high level), SMP Negeri 3 Taluk Kuantan (medium level) and SMP Negeri 2 Benai (low level). The research was conducted in these three schools, each school had 1 experimental class and 1 control class. The results showed that it was significant $0.000<0.05$, which means that there was an effect of the application of PBL on the student's MPSA in terms of overall students where the student's MPSA using the PBL model was better than students using conventional learning. Meanwhile, if viewed from the school level, it is obtained that it is significant $0.001<0.05$ (high level), $0.824>0.05$ (moderate level) and 0.140>0.05 (low level). This means that there is an effect of PBL application on MPSA at high levels and at medium and low school levels there is no significant effect.
\end{abstract}

Keywords : Problem Based Learning (PBL), Mathematical Problem Solving Ability

(MPSA)

\begin{abstract}
Abstrak
Tujuan penelitian ini adalah untuk mengetahui pengaruh penerapan model Problem Based Learning (PBL) terhadap kemampuan pemecahan masalah matematis (KPMM) siswa pada materi Aritmetika Sosial. Penelitian ini dilakukan untuk melihat pengaruh dari peenerapan model PBL terhadap KPMM siswa ditinjau dari keseluruhan siswa level tinggi, sedang dan rendah dan ditinjau dari setiap level sekolah yang menjadi sampel penelitian. Penelitian ini menggunakan metode eksperimen dengan pre-test post-test control group design. Populasi dalam penelitian ini adalah siswa kelas VII SMP Negeri se-Kabupaten Kuantan. Populasi berasal dari sekolah level tinggi, sedang, dan rendah. Sampel dalam penelitian ini adalah SMP Negeri 1 Taluk Kuantan (level tinggi), SMP Negeri 3 Taluk Kuantan (level sedang) dan SMP Negeri 2 Benai (level rendah). Penelitian dilakukan ditiga sekolah tersebut, setiap sekolah ada 1 kelas eksperimen dan 1 kelas kontrol. Hasil penelitian menunjukkan bahwa signifikan $0,000<0,05$ yang artinya terdapat pengaruh penerapan PBL terhadap KPMM siswa ditinjau dari keseluruhan siswa yang mana KPMM siswa dengan menggunakan model PBL lebih baik daripada siswa yang menggunakan pembelajaran konvensional. Sedangkan jika ditinjau dari level sekolah diperoleh signifikan 0,001 <0,05 (level tinggi), 0,824>0,05 (level sedang) dan 0,140>0,05 (level rendah). Hal ini berarti bahwa terdapat pengaruh penerapan PBL terhadap KPMM dilevel tinggi dan pada level sekolah sedang dan rendah tidak terdapat pengaruh yang signifikan.
\end{abstract}

Kata Kunci : Problem Based Learning (PBL), Kemampuan Pemecahan Masalah Matematis

\section{PENDAHULUAN}

Matematika merupakan sebuah ilmu yang sangat diperlukan dalam kehidupan, karena matematika adalah ilmu dasar yang digunakan untuk ilmu-ilmu yang lainnya serta sangat diperlukan dalam kehidupan sehari-hari dalam menyelesaikan sebuah masalah kontekstual. Matematika 
merupakan salah satu komponen penting dalam ilmu pengetahuan yang bersifat pasti, berdasarkan asal mulanya matematika (Haryono, 2014). Ilmu matematika diperoleh siswa melalui kegiatan belajar baik secara formal maupun informal. Pembelajaran matematika merupakan sebuah pertolongan yang guru berikan kepada siswa supaya bisa melakukan kegiatan pembelajaran untuk memperoleh suatu ilmu, memiliki kepandaian, serta membentuk tingkah laku dan rasa percaya diri khususnya pada materi Aritmetika Sosial.

Hampir semua masalah yang diberikan menuntut siswa untuk bisa berpikir tingkat tinggi dalam menyelesaikannya. Keadaan ini membuktikan bahwa kemampuan pemecahan masalah matematis (KPMM) itu sangat penting untuk melatih siswa dalam menyelesaikan permasalahan matematika khususnya pada Aritmetika sosial. Data hasil Ujian Nasional (UN) bidang studi matematika siswa SMP Negeri se-Kabupaten Kuantan Singingi dapat dilihat pada Tabel 1 dibawah ini.

\section{Tabel 1.}

Hasil Ujian Nasional Bidang Studi Matematika Siswa SMP se-Kabupaten Kuantan Singingi

\begin{tabular}{|c|c|}
\hline Interval Rerata UN & Jumlah Sekolah \\
\hline $23,02-27,02$ & 7 \\
\hline $28,02-31,02$ & 45 \\
\hline $32,02-36,02$ & 14 \\
\hline $37,02-41,02$ & 4 \\
\hline $42,02-46,02$ & 3 \\
\hline $47,02-51,02$ & 0 \\
\hline $52,02-56,02$ & 1 \\
\hline
\end{tabular}

Berdasarkan hasil UN diatas terlihat bahwa hasil UN siswa se-Kabupaten Kuantan Singingi masih rendah. Hal ini disebabkan oleh banyak hal, diantaranya adalah strategi pembelajaran, materi, pedekatan dan bahkan media pembelajaran yang digunakan. Rendahnya hasil UN juga dipengaruhi oleh rendahnya KPMM siswa. Menurut Sagala (Poima, 2016) mengatakan bahwa dalam sebuah pembelajaran khususnya pada materi Aritmetika Sosial diperlukan beberapa hal berikut: (1) mencari penjelasan; (2) memeriksa wawasan, (3) menumbuhkan tanggapan siswa; (4) melihat sampai dimana rasa ingin tahu siswa; (5) memahami apa yang telah diketahui siswa; (6) memusatkan minat siswa terhadap apa yang diinginkan guru; (7) memotivasi siswa untuk bertanya; (8) mengasah lagi pengetahuan siswa sebelumnya. Dalam pembelajaran matematika, siswa hendaknya memiliki lima dasar kemampuan untuk menguasai matematika dengan baik, yaitu kemampuan pemahaman konsep matematis, penalaran matematis, pemecahan masalah matematis, representasi matematis, dan memiliki sifat menghargai kegunaan matematika. Hal ini menunjukkan bahwa KPMM siswa perlu ditingkatkan untuk dapat meningkatkan kemampuan siswa dalam menguasai matematika. Untuk dapat meningkatkan KPMM siswa, peneliti menerapkan model Problem Based Learning (PBL) dikelas eksperimen.

Menurut (Sianturi et al., 2018) model Problem Based Learning (PBL), fokus pembelajaran ada pada masalah yang dipilih sehingga siswa tidak saja mempelajari konsep-konsep yang berhubungan 
dengan masalah tetapi juga metode ilmiah untuk memecahkan masalah tersebut. (Elizabeth \& Sigahitong, 2018) mengatakan bahwa PBL adalah proses pembelajaran yang titik awal pembelajaran berdasarkan masalah dalam kehidupan nyata. ( et al., 2016) juga mengatakan bahwa PBL merupakan model pembelajaran yang melibatkan siswa dalam memecahkan masalah nyata. Berdasarkan pendapat tersebut dapat disimpulkan bahwa PBL adalah model pembelajaran yang memulai aktifitas belajar dengan memberikan permasalahan kepada siswa dan melibatkan siswa dalam menyelesaikan masalah tersebut.

KPMM adalah sebuah kemampuan matematis yang sangat diperlukan siswa dalam belajar matematika (Hedriana, 2017). (Siregar \& Syafari, 2017) mengatakan bahwa KPMM merupakan kemampuan siswa untuk menyelesaikan atau menemukan jawaban dari suatu pertanyaan yang terdapat didalam suatu cerita, teks, dan tugas-tugas dalam pelajaran matematika sesuai langkahlangkah pemecahan masalah. (Purwosusilo, 2014) juga mengatakan bahwa KPMM meliputi kemampuan siswa dalam memahami masalah, merencanakan pemecahan masalah, dan melakukan perhitungan serta memeriksa kembali hasil perhitungan yang dilakukannya. (Mawaddah \& Anisah, 2015) juga mengatakan bahwa KPMM adalah memahami masalah yang meliputi kemampuan mengidentifikasi unsur-unsur yang diketahui dan ditanyakan, membuat rencana pemecahan masalah, melaksanakan rencana pemecahan masalah dan menafsirkan solusi yang diperoleh. Berdasarkan pendapat tersebut dapat disimpulkan bahwa KPMM merupakan sebuah kemampuan yang sangat penting dalam matematika dan harus dimiliki siswa untuk dapat menyelesaikan permasalahan matematika.

KPMM adalah sebuah kemampuan yang harus dimiliki siswa untuk dapat menyelesaikan permasalahan yang autentik (nyata) dalam kehidupan sehari-hari.Sumarmo (Hedriana, 2017) juga mengatakan bahwa pemecahan masalah matematis memiliki 2 arti yaitu sebagai sebuah strategi dalam belajar dan kegiatan dalam mengerjakan matematika. Namun pada kenyataannya, KPMM siswa masih tergolong sangat rendah jika dilihat dari hasil Ujian Nasional siswa Tahun 2017/2018 dan juga berdasarkan hasil Programme for International Student Assesment (PISA) dan Trends in International Mathematics and Science Study (TIMSS). Laporan PISA pada tahun 2015, skor matematika siswa Indonesia berada pada posisi 63 dari 70 negara peserta. Pada laporan TIMSS tahun 2011, siswa Indonesia berada pada posisi 38 dari 42 negara peserta (Utami \& Wutsqa, 2017).

Berdasarkan data UN, PISA dan TIMSS terlihat bahwa KPMM siswa masih tergolong sangat rendah. Untuk mengatasi rendahnya KPMM siswa disekolah SMP Negeri se-Kabupaten Kuantan Singingi maka peneliti menerapkan model PBL sebagai langkah untuk meningkatkan KPMM siswa. Indikator KPMM yang digunakan dalam penelitian ini adalah : (1) memahami masalah; (2) merancang langkah-langkah ataupun strategi untuk menyelesaikan masalah; (3) melaksanakan rencana dari strategi yang telah dirancang sebelumnya; (4) memeriksa kembali hasil dan solusi yang diperoleh. PBL merupakan sebuah model pembelajaran dimana kegiatan belajar dimulai dengan memberikan masalah yang berkaitan dengan dunia nyata atau kehidupan sehari-hari. (Arend, 2012) 
Pengaruh Model Problem Based Learning Terhadap Kemampuan Pemecahan Masalah Matematis Siswa Kelas VII SMPN Se-Kabupaten Kuantan Singingi Pada Materi Aritmetika Sosial, Erpina Ulva, Maimunah, Atma Murni

mendefenisikan PBL sebagai sebuah model pembelajaran yang mengharuskan siswa untuk berhadapan langsung dengan permasalahan yang autentik supaya siswa mampu merancang pengetahuannya sendiri, mengembangkan inquiri, keterampilan yang lebih tinggi dan membuat siswa lebih mandiri serta meningkatkan rasa percaya diri siswa.

Penelitian terdahulu terkait KPMM yang telah banyak dilakukan, diantaranya (Yusri, 2018) dan (Akbar et al., 2017). (Yusri, 2018) melakukan penelitian terkait penerapan PBL terhadap KPMM siswa, hasil penelitiannya adalah siswa yang belajar dengan menerapkan model PBL lebih baik daripada siswa yang menggunakan model konvensional dengan pendekatan saintifik. Kemudian hasil penelitian (Akbar et al., 2017) menyatakan bahwa KPMM siswa kelas XI SMA Putra Juang pada materi peluang termasuk dalam kategori rendah. Hal ini dapat dilihat dari banyaknya siswa yang menyelesaikan pada setiap indikator memahami masalah $48,75 \%$, merencanakan penyelesaian $40 \%$, menyelesaikan masalah 7,5\%, dan melakukan pengecekan 0\%. Berdasarkan hasil penelitian yang dilakukan Andi terlihat bahwa model PBL dapat meningkatkan KPMM siswa dibandingkan dengan siswa yang menggunakan model kovensional.

Penelitian ini mengkaji KPMM dengan menerapkan model PBL dalam pembelajaran. Penelitian dilakukan terhadap siswa kelas VII SMP Negeri se-Kabupaten Kuantan Singingi pada seluruh level tinggi, sedang dan rendah.

\section{METODE}

Jenis penelitian ini adalah penelitian kuantitatif dengan metode eksperimental semu. Desain penelitian menggunakan Pretest-Posttest Control Group Design seperti Tabel 2 dibawah ini.

\section{Tabel 2.}

Keterkaitan Model Pembelajaran dan Level Sekolah

\begin{tabular}{|c|c|c|}
\hline \multirow{2}{*}{ Level Sekolah } & \multicolumn{2}{|c|}{ Pembelajaran } \\
\cline { 2 - 3 } & PBL & Konvensional \\
\hline Tinggi (T) & PBL (T) & KT \\
\hline Sedang (S) & PBL (S) & KS \\
\hline Rendah (R) & PBL (R) & KR \\
\hline
\end{tabular}

\begin{tabular}{|c|c|c|c|}
\hline Kelompok & Pretes & Perlakuan & Postes \\
\hline Ekperimen 1 & $\mathrm{O}_{\mathrm{T} 1}$ & $\mathrm{X}$ & $\mathrm{O}_{\mathrm{T} 2}$ \\
\hline Kontrol 1 & $\mathrm{O}_{\mathrm{KT} 1}$ & - & $\mathrm{O}_{\mathrm{KT} 2}$ \\
\hline Ekperimen 2 & $\mathrm{O}_{\mathrm{S} 1}$ & $\mathrm{X}$ & $\mathrm{O}_{\mathrm{S} 2}$ \\
\hline Kontrol 2 & $\mathrm{O}_{\mathrm{KS} 1}$ & - & $\mathrm{O}_{\mathrm{KS} 2}$ \\
\hline Ekperimen 3 & $\mathrm{O}_{\mathrm{R} 1}$ & $\mathrm{X}$ & $\mathrm{O}_{\mathrm{R} 2}$ \\
\hline Kontrol 3 & $\mathrm{O}_{\mathrm{KR} 1}$ & - & $\mathrm{O}_{\mathrm{KR} 2}$ \\
\hline
\end{tabular}

Gambar 1. Rancangan Eksperimen (pretes dan postes Control Group Desaign) 


\section{Keterangan:}

KT : Kelas konvensional level tinggi.

KS : Kelas konvensional level sedang.

KR : Kelas konvensional rendah rendah.

$\mathrm{T} \quad$ : Kelas eksperimen level tinggi.

S : Kelas eksperimen level sedang.

$\mathrm{R} \quad$ : Kelas eksperimen level rendah.

$\mathrm{O}_{\mathrm{T} 1} \quad$ : Pretes kelompok kelas eksperimen 1

$\mathrm{O}_{\mathrm{T} 2} \quad$ :Postes kelompok kelas konvensional 1

Populasi dalam penelitian ini adalah seluruh siswa kelas VII SMP Negeri se-Kabupaten Kuantan Singingi yang terdiri dari 73 sekolah Negeri, yang dikelompokkan menjadi level tinggi, sedang dan rendah. Setiap level dipilih satu sekolah secara acak. Dari setiap sekolah ditetapkan dua kelas sampel yang homogen. Sampel dalam penelitian ini adalah SMP Negeri 1 Teluk Kuantan (level tinggi), SMP Negeri 3 Teluk Kuantan (level sedang) dan SMP Negeri 2 Benai (level rendah). Pada level tinggi yang menjadi kelas eksperimen dan kontrol adalah kelas VII.4 dan VII.6. Level sedang yang menjadi kelas eksperimen dan kontrol adalah kelas VII.1 dan VII.3. Sedangkan level rendah yang menjadi kelas eksperimen dan kontrol adalah kelas VII.1 dan VII.2.

Instrumen tes yang digunakan untuk melihat KPMM siswa dibuat berdasarkan indikator dari KPMM yang disesuaikan juga dengan materi yang diteliti dan kisi-kisi tes. Tes dibuat berbentuk sebuah permasalahan yang sering ditemui dalam kehidupan sehari-hari. Instrumen tes divalidasi oleh validator untuk di analisa kelayakan dari tes KPMM tersebut sebelum dibagikan kepada siswa saat penelitian. Data yang diperoleh terdiri dari 2 jenis data yaitu data pretest dan data postest. Data tersebut kemudian dianalisis menggunakan teknik analisis data yang terdiri dari uji normalitas, uji homogenitas dan uji kesamaan rata-rata. Uji normalitas, uji homogenitas dan uji kesamaan rata-rata merupakan sebuah prasyarat awal untuk melakukan pengujian dengan statistika parametrik dengan syarat data berditribusi normal, homogen dan tidak terdapat perbedaan antara kelas eksperimen dan kelas kontrol. Selanjutnya pengujian hipotesis dilakukan dengan menggunakan uji $t$-test untuk melihat pengaruh penerapan PBL terhadap KPMM ditinjau dari keseluruhan siswa dan uji oneway anova untuk melihat pengaruh penerapan PBL terhadap KPMM ditinjau dari level sekolah tinggi, sedang dan rendah.

\section{HASIL}

Perangkat pembelajaran dalam penelitian ini mengacu pada model PBL dengan materi Aritmetika Sosial kelas VII SMP. Penelitian ini dilakukan untuk melihat apakah terdapat pengaruh penerapan model PBL terhadap KPMM yang telah memenuhi kriteria valid dan efektif dalam meningkatkan KPMM. Tahap pelaksanaan penelitian eksperimen diawali dengan mengelompokkan satu kelas eksperimen dan satu kelas kontrol pada masing-masing sekolah yang berada pada level 
Pengaruh Model Problem Based Learning Terhadap Kemampuan Pemecahan Masalah Matematis Siswa Kelas VII SMPN Se-Kabupaten Kuantan Singingi Pada Materi Aritmetika Sosial, Erpina Ulva, Maimunah, Atma Murni

tinggi, sedang dan rendah. Selanjutnya, siswa diberikan pretest untuk melihat kemampuan awal siswa. Supaya tidak terjadi pembiasan dalam perlakuan pada kelas eksperimen yang diteliti, maka dalam pelaksanaan pembelajaran peneliti berperan sebagai guru. Setelah semua pembelajaran selesai, diberikan posttest berupa tes untuk kemampuan pemecahan masalah kepada enam kelas dari keseluruhan level. Pretest dan postest KPMM siswa di sekolah level tinggi, sedang dan rendah dapat dilihat pada Gambar 2.

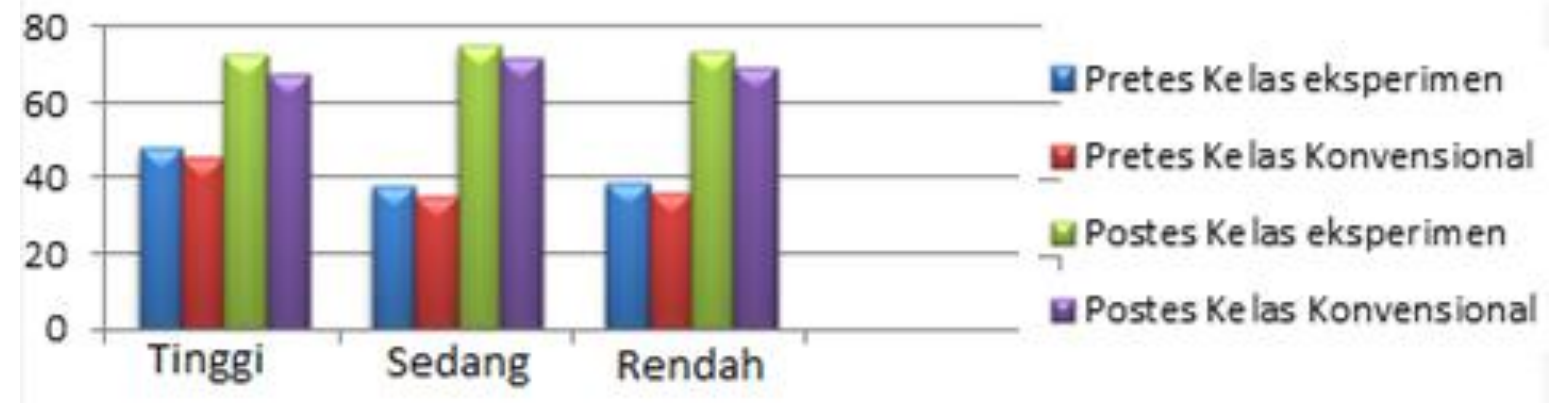

Gambar 2. Nilai Pretest Dan Postest Siswa Kelas Eksperimen dan Konvensional

Berdasarkan rekapitulasi postest siswa pada Gambar 2, terlihat bahwa terjadi peningkatan untuk KPMM siswa setelah mengikuti pembelajaran dengan menggunakan model PBL.

Berdasarkan hasil pengolahan normalitas untuk KPMM siswa pada kelas eksperimen dan konvensional dengan taraf signifikan 5\% diperoleh hasil signifikansi normalitas $>0,05$ dimana $\mathrm{H}_{0}$ diterima dan $\mathrm{H}_{\mathrm{a}}$ ditolak artinya data berdistribusi normal. Kemudian untuk pengujian normalitas motivasi belajar pada kelas eksperimen dan konvensional diperoleh signifikansi normalitas >0,05 dimana $\mathrm{H}_{0}$ diterima dan $\mathrm{H}_{\mathrm{a}}$ ditolak artinya data berdistribusi normal. Pengujian analisis data postest KPMM bertujuan untuk mengetahui apakah ada pengaruh penerapan PBL terhadap KPMM siswa kelas VII pada materi Aritmetika Sosial ditinjau dari keseluruhan siswa di SMP Negeri se-Kabupaten Kuantan Singingi. Peneliti melakukan pengujian hipotesis dengan menggunakan uji $t$-test. Hasil dari pengujian hipotesis dideskripsikan dalam Tabel 3 berikut.

\section{Tabel 3.}

Hasil Pengujian Hipotesis

\begin{tabular}{|c|c|c|c|c|c|c|c|}
\hline Kelas & $\mathrm{N}$ & $\begin{array}{c}\text { Rata- } \\
\text { rata }\end{array}$ & $\mathrm{T}$ & Signifikan & $\mathrm{H}_{\mathrm{o}}$ & $\mathrm{H}_{\mathrm{a}}$ & Keterangan \\
\hline Eksperimen & 85 & 77 & 3,938 & 0,000 & Ditolak & Diterima & $\begin{array}{c}\text { Ada } \\
\text { Pengaruh }\end{array}$ \\
\hline Kontrol & 79 & 71 & & & & &
\end{tabular}

Tabel 3 menunjukkan $H_{0}$ ditolak sehingga dapat disimpulkan bahwa terdapat pengaruh positif penerapan PBL terhadap KPMM siswa kelas VII pada materi Aritmetika Sosial ditinjau dari keseluruhan siswa di SMP Negeri se-Kabupaten Kuantan Singingi. Pengujian analisis data postest KPMM juga bertujuan untuk mengetahui apakah ada pengaruh penerapan PBL terhadap KPMM siswa kelas VII pada materi Aritmetika Sosial ditinjau dari level sekolah tinggi, sedang, dan rendah di 
SMP Negeri se-Kabupaten Kuantan Singingi. Peneliti melakukan pengujian hipotesis dengan menggunakan uji one way anova. Hasil dari pengujian hipotesis dideskripsikan dalam Tabel 4 berikut.

Tabel 4.

Hasil Pengujian Hipotesis

\begin{tabular}{|c|c|c|c|c|c|c|c|c|}
\hline $\begin{array}{c}\text { Level } \\
\text { Sekolah }\end{array}$ & Kelas & $\mathbf{N}$ & Rata-Rata & $\mathbf{F}$ & Sig & $\mathbf{H}_{\mathbf{0}}$ & $\mathbf{H}_{\mathbf{a}}$ & Ket \\
\hline \multirow{2}{*}{ Tinggi } & Eksperimen & 30 & 79 & \multirow{2}{*}{13,272} & \multirow{2}{*}{0,001} & \multirow{2}{*}{ Ditolak } & \multirow{2}{*}{ Diterima } & Ada \\
\hline & Kontrol & 30 & 68 & & & & & Pengaruh \\
\hline \multirow[b]{2}{*}{ Sedang } & Eksperimen & 27 & 78 & \multirow[b]{2}{*}{0,050} & \multirow[b]{2}{*}{0,824} & \multirow[b]{2}{*}{ Diterima } & \multirow[b]{2}{*}{ Ditolak } & \multirow{2}{*}{$\begin{array}{l}\text { Tidak Ada } \\
\text { Pengaruh }\end{array}$} \\
\hline & Kontrol & 23 & 77 & & & & & \\
\hline \multirow{2}{*}{ Rendah } & Eksperimen & 28 & 74 & \multirow{2}{*}{2,246} & \multirow{2}{*}{0,140} & \multirow{2}{*}{ Diterima } & \multirow{2}{*}{ Ditolak } & Tidak Ada \\
\hline & Kontrol & 26 & 70 & & & & & Pengaruh \\
\hline
\end{tabular}

Hasil yang disajikan pada Tabel 4 menunjukkan bahwa terdapat pengaruh penerapam PBL terhadap KPMM siswa kelas VII pada materi Aritmetika Sosial di sekolah level tinggi, sedangkan untuk sekolah level sedang dan rendah tidak terdapat pengaruh.

Hasil pengujian pada hipotesis 1 menyatakan bahwa terdapat pengaruh penerapan PBL terhadap KPMM siswa kelas VII ditinjau dari keseluruhan siswa SMP Negeri se-Kabupaten Kuantan Singingi pada materi Aritmetika Sosial .Pada saat penelitian ini berlangsung hingga dua pertemuan, terdapat suatu kendala dalam menerapannya, yaitu sekolah terpaksa diliburkan karena adanya wabah virus Covid-19 yang mengakibatkan siswa dan guru tidak dapat melakukan proses belajar mengajar seperti biasanya disekolah. Penyebaran wabah Covid-19 menyebabkan siswa harus belajar di rumah masing-masing, sehingga peneliti sebagai guru pengajar pada materi Aritmetika Sosial memberikan tugas melalui pesan Whatsapp kepada siswa untuk dapat mengerjakan permasalahan-permasalahan yang terdapat dalam LKPD untuk pertemuan tiga sampai dengan pertemuan enam. Meskipun pembelajaran dilakukan secara daring namun LKPD yang dibuat berdasarkan model PBL tetap memberikan pengaruh yang positif terhadap KPMM siswa ditinjau dari keseluruhan.

Pada penelitian ini juga ditemukan pada analisis hipotesis 2 terdapat pengaruh yang signifikan pada penerapan model PBL terhadap KPMM pada sekolah level tinggi, sedangkan untuk sekolah level sedang dan rendah tidak terdapat pengaruh pada penerapan model PBL terhadap KPMM. Proses pengambilan data KPMM dilakukn secara daring dengan memberikan LKPD kepada siswa dengan langkah-langkah yang mudah untuk dipahami.Siswa pada level kelas tinggi tetap memberikan pengaruh yng positif dari penerapan model PBL terhadap KPMM siswa kelas VII ditinjau dari level sekolah tinggi. Namun sebaliknya dengan sekolah level sedang dan rendah tidak memberikan pengaruh yang signifikan karena kebanyakan siswa pada sekolah level sedang dan rendah menjawab LKPD tidak sesuai dengan langkah-langkah yang telah ada di LKPD. Bahkan ada siswa di sekolah level sedang dan rendah yang tidak mengumpulkan tugasnya sampai waktu yang telah ditentukan 
serta tidak mengikuti ulangan harian materi Aritmetika Sosial tanpa menghubungi gurunya sama sekali. Hal ini bisa menjadi alasan bahwa penerapan model PBL di sekolah level sedang dan rendah tidak memberikan pengaruh yang signifikan karena siswanya yang tidak peduli dengan tugas yang diberikan gurunya.

\section{KESIMPULAN}

Penerapan model PBL lebih baik digunakan untuk meningkatkan KPMM siswa bila ditinjau dari keseluruhan siswa tanpa memandang level sekolahnya. Berdasarkan analisis data penelitian yang telah dilakukan, peneliti mengambil kesimpulan sebagai berikut.

1. Terdapat pengaruh penerapan Problem Based Learning $(P B L)$ terhadap kemampuan pemecahan masalah matematis (KPMM) siswa kelas VII pada materi Aritmetika Sosial ditinjau dari keseluruhan siswa di SMP Negeri se-Kabupaten Kuantan Singingi.

2. Terdapat pengaruh penerapan Problem Based Learning $(P B L)$ terhadap kemampuan pemecahan masalah matematis (KPMM) siswa kelas VII pada materi Aritmetika Sosial ditinjau dari level sekolah tinggi, sedangkan untuk sekolah level sedang dan rendah tidak terdapat pengaruh yang signifikan di SMP Negeri se-Kabupaten Kuantan Singingi.

\section{DAFTAR PUSTAKA}

Akbar, P., Hamid, A., Bernard, M., \& Sugandi, A. I. (2017). Analisis Kemampuan Pemecahan Masalah Dan Disposisi Matematik Siswa Kelas Xi Sma Putra Juang Dalam Materi Peluang. Jurnal Cendekia: Jurnal Pendidikan Matematika, 2(1), 144-153. https://doi.org/10.31004/cendekia.v2i1.62

Arend, R. (2012). Learning to Teach Ninth Edition.

Elizabeth, A., \& Sigahitong, M. M. (2018). Pengaruh Model Problem Based Learning Terhadap Kemampuan Berpikir Kreatif Peserta Didik SMA. Prisma Sains : Jurnal Pengkajian Ilmu Dan Pembelajaran Matematika Dan IPA IKIP Mataram, 6(2), 66. https://doi.org/10.33394/jps.v6i2.1044

Haryono, D. (2014). Filsafat Matematika. ALFABETA.

Hedriana, H. (2017). Penilaian Pembelajaran Matematika. PT. REFIKA ADITAMA.

Indah, N., Mania, S., \& Nursalam, N. (2016). Peningkatan Kemampuan Literasi Matematika Siswa Melalui Penerapan Model Pembelajaran Problem Based Learning Di Kelas Vii Smp Negeri 5 Pallangga Kabupaten Gowa. MaPan, 4(2), 200-210. https://doi.org/10.24252/mapan.2016v4n2a4

Mawaddah, S., \& Anisah, H. (2015). Kemampuan Pemecahan Masalah Matematis Siswa Pada Pembelajaran Matematika dengan Menggunakag) di SMPn Model Pembelajaran Generatif (Generative Learning) di SMP. EDU-MAT: Jurnal Pendidikan Matematika, 3(2), 166-175. https://doi.org/10.20527/edumat.v3i2.644 
Poima, D. M. (2016). Profil Pemecahan Masalah Matematika pada Materi Perbandingan dan Skala Berdasarkan Tahapan Polya bagi Siswa Kelas VI SD Kristen 03 Eben Haezer Salatiga. http://repository.uksw.edu/handle/123456789/9768

Purwosusilo, P. (2014). Peningkatan Kemampuan Pemahaman Dan Pemecahan Masalah Matematik Siswa SMK Melalui Strategi Pembelajaran React (Studi Eksperimen Di SMK Negeri 52 Jakarta). Jurnal Pendidikan Dan Keguruan, 1(2), 209674.

Sianturi, A., Sipayung, T. N., \& Simorangkir, F. M. A. (2018). Pengaruh Model Problem Based Learning (PBL) Terhadap Kemampuan Berpikir Kritis Matematis Siswa SMPN 5 Sumbul. UNION: Jurnal Ilmiah Pendidikan Matematika, 6(1), 29-42. https://doi.org/10.30738/.v6i1.2082

Siregar, N. H., \& Syafari. (2017). Kemampuan Pemecahan Masalah Matematis Siswa Dalam Pembelajaran Matematika Menggunakan Model Pembelajaran Pbl Dan Tps. Semnastika Unimed, 1-10. http://digilib.unimed.ac.id/id/eprint/26922

Utami, R. W., \& Wutsqa, D. U. (2017). Analisis kemampuan pemecahan masalah matematika dan self-efficacy siswa SMP negeri di Kabupaten Ciamis. Jurnal Riset Pendidikan Matematika, 4(2), 166. https://doi.org/10.21831/jrpm.v4i2.14897

Yusri, A. Y. (2018). Pengaruh Model Pembelajaran Problem Based Learning Terhadap Kemampuan Pemecahan Masalah Matematika Siswa Kelas Vii Di Smp Negeri Pangkajene. Mosharafa: Jurnal Pendidikan Matematika, 7(1), 51-62. https://doi.org/10.31980/mosharafa.v7i1.341 